\title{
STUDI PEMANFAATAN LIMBAH BOTTOM ASH SEBAGAI ADSORBEN ZAT WARNA PADA INDUSTRI TEKSTIL (STUDI KASUS PT. TCI KABUPATEN BANDUNG)
}

\author{
NUR REZKY ARIFATUNNISA ${ }^{1}$, PRISMITA NURSETYOWATI ${ }^{1}$, DYAH \\ MARGANINGRUM ${ }^{2}$
}

1. Jurusan Teknik Lingkungan, Fakultas Teknik dan Ilmu Komputer, Universitas Bakrie, Jakarta 2. Pusat Penelitian Geoteknologi - Lembaga Ilmu Pengetahuan Indonesia (LIPI), Bandung Email : rezky7444@gmail.com

\begin{abstract}
ABSTRAK
PT. TCI merupakan industri tekstil yang mengolah benang hingga menjadi kain. Limbah yang dihasilkan dari Indutri tekstil berupa bottom ash dan limbah cair dapat bersifat mutagenik dan karsinogenik apabila dibiarkan terlalu lama di lingkungan. Penelitian ini bertujuan untuk mengetahui karakteristik dan kapasitas adsorpsi bottom ash yang telah disintesis untuk mengadsorpsi zat warna yang terkandung dalam limbah cair industri tekstil PT. TCI. Metode yang digunakan dalam penelitian ini adalah metode adsorpsi. Aktivasi bottom ash dilakukan dengan pemanasan pada suhu $50^{\circ} \mathrm{C}$ dan $100^{\circ} \mathrm{C}$ selama 1 jam. Dalam penelitian ini dilakukan variasi terhadap $\mathrm{pH}(2,3,4,5,6,7,8,9)$ dan waktu $\operatorname{kontak}(15,30,45,60,90,120,150,180$ menit) dengan limbah zat warna sebanyak $150 \mathrm{~mL}$. Hasil dari penelitian ini menunjukkan bahwa sintesis bottom ash dapat digunakan sebagai adsorben untuk menurunkan kadar zat warna pada limbah cair dengan pH dan waktu kontak optimum pada pembakaran $50^{\circ} \mathrm{C}$ dan $100^{\circ} \mathrm{C}$ masing-masing $\mathrm{pH} 5$ pada menit ke 90 dan pH 6 pada menit ke 180. Proses adsorpsi ini mengikuti jenis isotherm Freundlich dengan presentase adsorpsi optimum 31,804\%.
\end{abstract}

Kata Kunci : Adsorpsi, bottom ash, industri tekstil, zat warna.

\begin{abstract}
PT. TCI is a textile industry that processes yarn into fabrics. The waste produced from the textile industry such as bottom ash and dyes wastewater can be mutagenic and carsinogenic if its too long in the environment. This study aims to determine the characterization and adsorption capacity of activated bottom ash to adsorb the liquid waste from PT. TCI. The method of this study is adsorption. The bottom ash activation was done by hydrothermal method at $50^{\circ} \mathrm{C}$ and $100^{\circ} \mathrm{C}$ for 1 hour respectively. In the adsorption process, variation of $\mathrm{pH}(2,3,4,5,6,7,8,9)$ and contact time $(15,30,45,60,90,120,150,180$ minutes) was done with $150 \mathrm{~mL}$ of dyes wastewater. The result of this study showed that syhnthesized bottom ash can be used as an adsorbent to reduce the dyes on the wastewater. The optimum $\mathrm{pH}$ and contact time at the combustion of $50^{\circ} \mathrm{C}$ and $100^{\circ} \mathrm{C}$ were $\mathrm{pH} 5$ at 90 minutes and $\mathrm{pH} 6$ at 180 minutes respectively. The adsorption followed the Freundlich isotherm process type with the optimum adsorption percentage of $31,804 \%$.
\end{abstract}

Keywords : Adsorption, bottom ash, dyes wastewater, textile industry. 


\section{PENDAHULUAN}

Industri tekstil merupakan salah satu industri yang berkembang cukup pesat di Indonesia karena merupakan salah satu industri prioritas nasional yang masih prospekif untuk dikembangkan hingga menjadikan industri tekstil sebagai salah satu industri manufaktur terbesar di Indonesia, salah satunya PT. Tata Cakra Investama (PT.TCI) yang berlokasi di Cicalengka, Kabupaten Bandung. PT. TCI merupakan salah satu jenis industri tekstil polyester yang berproduksi mulai dari persiapan benang hingga menghasilkan kain. Proses produksi yang dilakukan untuk mengahasilkan sebuah produk tentu memiliki efek samping yaitu banyaknya limbah sisa pembakaran batubara.

Produksi tekstil dimulai dari pemintalan serat sampai menjadi kain (tekstil) dengan melewati beberapa tahap proses yang tentu saja akan menghasilkan limbah baik limbah cair, limbah gas, maupun limbah padat. Limbah cair dihasilkan dari proses dyeing (pewarnaan), washing (pencucian), sizing (pengkanjian), printing (pencetakkan), dan finishing (pengeringan). Sementara limbah padat dihasilkan dari proses pembakaran batubara yang digunakan sebagai bahan bakar dengan komposisi $\mathrm{C}, \mathrm{H}, \mathrm{O}, \mathrm{N}, \mathrm{S}$, dan abu yang tidak ramah terhadap lingkungan. Pembakaran batubara ini menghasilkan limbah padat berupa fly ash sekitar 8090\% bottom ash 10-20\% (Herfina, 2017).

Studi ini bertujuan untuk mengetahui seberapa besar zat warna pada limbah cair yang dapat diadsorpsi oleh bottom ash yang dihasilkan dari PT TCI. Beberapa penelitian telah dilakukan terhadap pemanfaatan bottom ash sebagai adsorben. Berdasarkan penelitian yang dilakukan oleh Khan (2009) uji adsorpsi untuk menghilangkan methylene blue, malachite green dan rhodamin $B$ dilakukan dengan memvariasikan $\mathrm{pH}$ yaitu 3, 5, 7, dan 9. Triawan (2017) melakukan uji adsorpsi untuk menghilangkan methylene blue dengan memvariasikan waktu kontak yaitu 10, 20, 40, 60, 80, 100, 120, 150 menit, sedangkan Sutrisno (2014) juga melakukan penelitian untuk mengadsorpsi Rhodamin $\mathrm{B}$ dengan memvariasikan waktu kontak yaitu 10, 20, 30, 40, 50 dan 60 menit. Aktivasi bottom ash sebagai adsorben dilakukan pada suhu $100^{\circ} \mathrm{C}$ selama 1 jam (Murniati, 2009).

\section{BAHAN DAN METODE}

\subsection{Prosedur Penelitian}

1. Kurva standar larutan

Penentuan kurva standar dilakukan dengan menggunakan spektrofotometer dengan panjang gelombang $410 \mathrm{~nm}$.

2. Persiapan abu batubara

Sampel bottom ash ditimbang 100gr dan diaktivasi menggunakan oven pada suhu $50^{\circ} \mathrm{C}$ dan $100^{\circ} \mathrm{C}$ selama 1 jam.

3. Persiapan limbah cair

Limbah cair zat warna disaring menggunakan kertas saring terlebih dahulu untuk mengurangi kadar kekeruhan yang terdapat pada limbah.

4. Penentuan $\mathrm{pH}$ optimum

Dilakukan variasi terhadap $\mathrm{pH}$ yaitu 2, 3, 4, 5, 6, 7, 8, 9 kemudian diukur adsorbansinya menggunakan spektrofotometer

5. Penentuan waktu kontak optimum

Dilakukan variasi terhadap waktu kontak yaitu 15, 30, 45, 60, 90, 120, 150, dan 180 menit yang kemudian diukur adsorbansinya dengan spektrofotometer.

6. Penentuan kapasitas adsorpsi akan dilakukan dengan menggunakan persamaan berikut (Zhao et al., 2013) 


$$
q e=\frac{(\mathrm{Co}-\mathrm{Ce}) \mathrm{V}}{m}
$$

Menurut Dong et al., (2010) penentuan kapasitas adsorpsi maksimum menggunakan persaman isotherm Langmuir, yaitu :

$$
\frac{\mathrm{Ce}}{\mathrm{qe}}=\frac{1}{\mathrm{~K}_{\mathrm{L}} \mathrm{q}_{\max }}+\frac{\mathrm{Ce}}{\mathrm{qmax}}
$$

Sedangkan persamaan isotherm Freundlich yaitu :

$$
\ln \mathrm{q}_{\mathrm{e}}=\ln \mathrm{K}_{\mathrm{f}}+\frac{1}{\mathrm{n}} \mathrm{Ce}
$$

Keterangan :

m : massa adsorben yang digunakan (gram)

$\mathrm{V} \quad$ : volume larutan (Liter)

$\mathrm{q}_{\mathrm{e}} \quad$ : jumlah molekul zat warna yang teradsorpsi pada keadaan setimbang $(\mathrm{mg} / \mathrm{g})$

$\mathrm{q}_{\max } \quad$ : kapasitas maksimal adsorpsi $(\mathrm{mg} / \mathrm{g})$

$\mathrm{K}_{\mathrm{L}} \quad$ : Konstanta Langmuir $(\mathrm{L} / \mathrm{g})$

$\mathrm{K}_{\mathrm{f}} \quad$ : Konstanta empiric isotherm Freundlich (L/mg)

\subsection{Diagram Alir Penelitian}

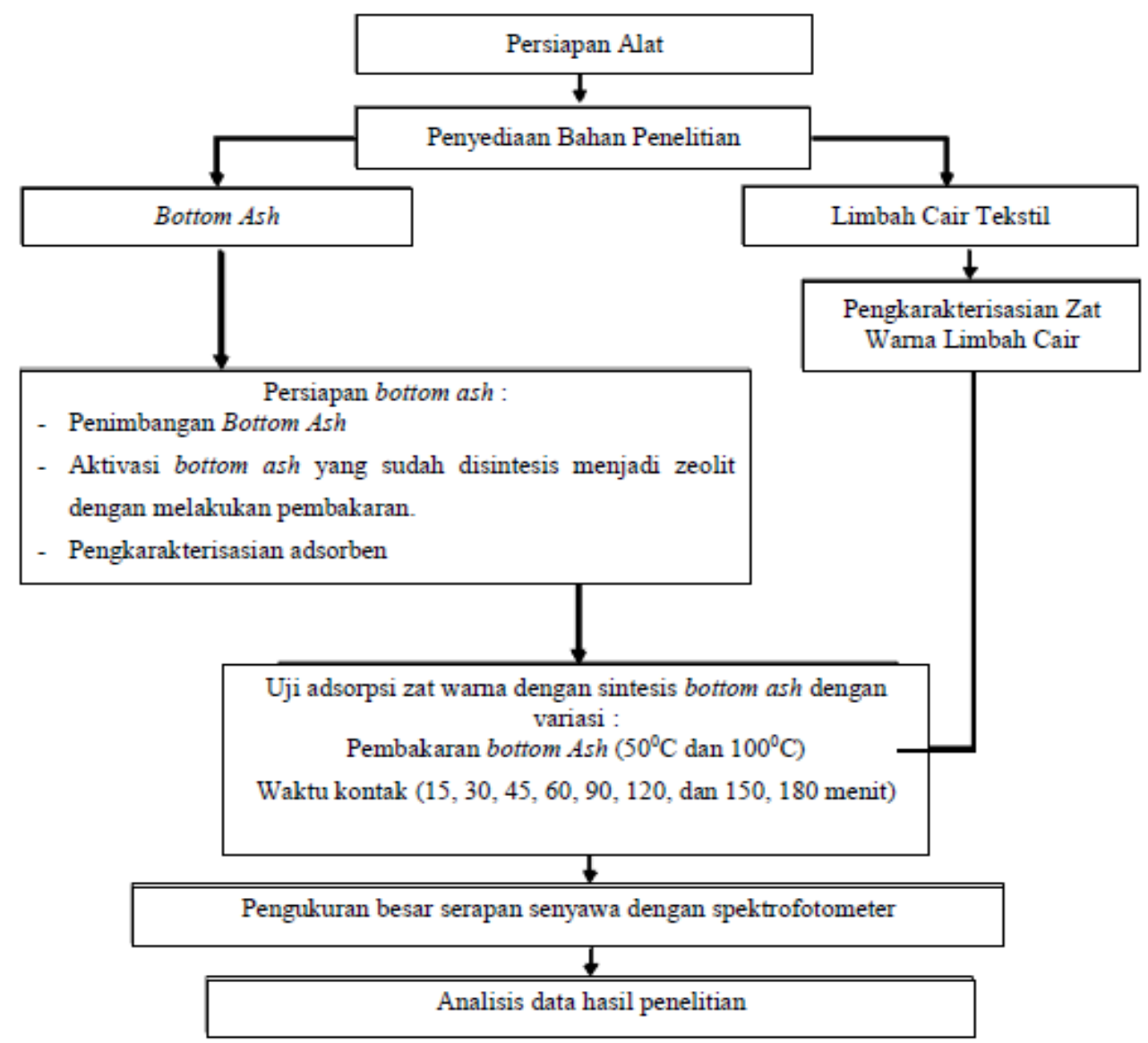

Gambar 1. Diagram Alir

\section{PEMBAHASAN}

\subsection{Karakteristik Bottom Ash}

Pengkarakterisasian bottom ash dilakukan dengan menggunakan uji XRF untuk mengetahui komposisi logam berat dan kadarnya (\%). Menurut Jayaranjan (2014) coal bottom ash 
memiliki kandungan silikat, karbon, alum allum, serta beberaoa kandungan logam berat dan metalloid namun dengan komposisi pada setiap bottom ash akan berbeda bergantung pada sumber, ukuran jenis batubara, dan jenis pembakarannya. Hasil karakterisasi XRF ini didapatkan dengan cara studi literatur terhadap beberapa penelitian yang menggunakan bottom ash sebagai adsorben seperti penelitian yang dilakukan Wardani (2012) dan Benzaoui (2017) untuk menurunkan kandungan ion logam, Yunita (2017) melakukan penelitian terkait pengkarakterisasian fly ash dan bottom ash, Kusmiyati (2016) menghilangkan warna vertigo blue dan Bertolini (2013) menghilangkan warna crystal violet, Tarigan (2017) menghilangkan kandungan fosfat selanjutnya dapat dilihat pada tabel berikut

Tabel 1. Komposisi Bottom Ash Sebelum dan Setelah Aktivasi

\begin{tabular}{|c|c|c|c|c|c|c|c|c|}
\hline \multirow{2}{*}{ Unsur } & \multicolumn{2}{|c|}{ Wardani, 2012} & \multirow{2}{*}{$\begin{array}{c}\text { Benzaoui, } \\
2017\end{array}$} & \multirow{2}{*}{$\begin{array}{c}\text { Yunita, } \\
2017\end{array}$} & \multirow{2}{*}{$\begin{array}{c}\text { Kusmiyati, } \\
2016\end{array}$} & \multirow{2}{*}{$\begin{array}{c}\text { Tarigan, } \\
2019\end{array}$} & \multirow{2}{*}{$\begin{array}{c}\text { Yildirim, } \\
2017\end{array}$} & \multirow{2}{*}{$\begin{array}{c}\text { Bertolini, } \\
2013\end{array}$} \\
\hline & Sebelum & Setelah & & & & & & \\
\hline Al & 3,4 & 1 & 1,703 & 4,51 & 24,64 & & 15,4 & 38 \\
\hline Si & 7,46 & 4,2 & 0,527 & 33,67 & 45,8 & & 47,5 & 33 \\
\hline $\mathbf{S}$ & 0,63 & & 0,053 & & & & 5,10 & 0,24 \\
\hline$K$ & 0,65 & 0 & 0,440 & 1,30 & 2,05 & & 2,05 & 0,7 \\
\hline $\mathrm{Ca}$ & 56,7 & 57,1 & 7,873 & 8,61 & 4,036 & & 8,33 & 2,7 \\
\hline $\mathrm{Ti}$ & 1,0 & 1,4 & 4,038 & 1,62 & 6,16 & 6,058 & & 2,0 \\
\hline $\mathbf{V}$ & 0,05 & 0,08 & & & & & & \\
\hline $\mathrm{Cr}$ & 0,075 & 0,14 & & & 0,03 & & & \\
\hline Mn & 0,28 & 0,35 & & & 0,12 & 1,035 & & \\
\hline Fe & 22,1 & 30,2 & & 46,51 & 16,6 & 55,314 & 11,6 & 13 \\
\hline $\mathbf{N i}$ & 0,18 & 0,29 & & & & & & \\
\hline $\mathbf{C u}$ & 0,082 & 0,17 & & & 0,2 & & & \\
\hline Sr & 0,58 & 1,0 & & & & & & \\
\hline Mo & 4,0 & & & & & & & \\
\hline In & 1,9 & 1,6 & & & & & & \\
\hline $\mathbf{B a}$ & 0,4 & 0,79 & & & & & & \\
\hline Yb & 0,06 & & & & & & & \\
\hline $\mathbf{R e}$ & 0,35 & & & & & & & \\
\hline C & & & 53,161 & & & & & \\
\hline 0 & & & 31,06 & & & & & \\
\hline $\mathrm{Na}$ & & & 0,176 & & & & 1,79 & 8,0 \\
\hline Mg & & & 0,498 & & & & 8,08 & 1,4 \\
\hline $\mathbf{P}$ & & & 0,498 & & & & 0,221 & \\
\hline $\mathbf{C l}$ & & & 0,032 & & & & & \\
\hline $\mathrm{Br}$ & & & & & & & & 0,05 \\
\hline \multicolumn{9}{|l|}{$\mathbf{U}$} \\
\hline $\mathrm{Zr}$ & & & & & & 2,291 & & 0,04 \\
\hline \multicolumn{9}{|l|}{$\mathbf{Y}$} \\
\hline Zn & & & & & & 22,192 & & 0,02 \\
\hline Sb & & & & & & 13,110 & & \\
\hline
\end{tabular}

\subsection{Penentuan pH Optimum}

Derajat keasaman $(\mathrm{pH})$ merupakan salah satu hal yang berpengaruh terhadap banyaknya konsentrasi serapan yang dilakukan oleh adsorben terhadap adsorbat. Penentuan $\mathrm{pH}$ optimum dilakukan dengan memvariasikan $\mathrm{pH}$ yaitu 2, 3, 4, 5, 6, 7, 8, dan 9. Pada pembakaran $50^{\circ} \mathrm{C}$ dalam waktu 180 menit adsorpsi optimum terjadi pada pH 5 dengan kadar zat warna dalam limbah cair dari $27,019 \mathrm{mg} / \mathrm{L}$ turun menjadi $23,849 \mathrm{mg} / \mathrm{L}$, sedangkan pada pembakaran $100^{\circ} \mathrm{C}$ dalam waktu 180 menit adsorpsi optimum terjadi pada $\mathrm{pH} 6$ dengan 
kadar zat warna dalam limbah cair sebesar 30,257 mg/L turun menjadi 20,634 mg/L. Hasil serapan dapat dilihat pada gambar 2 dan gambar 3 berikut.

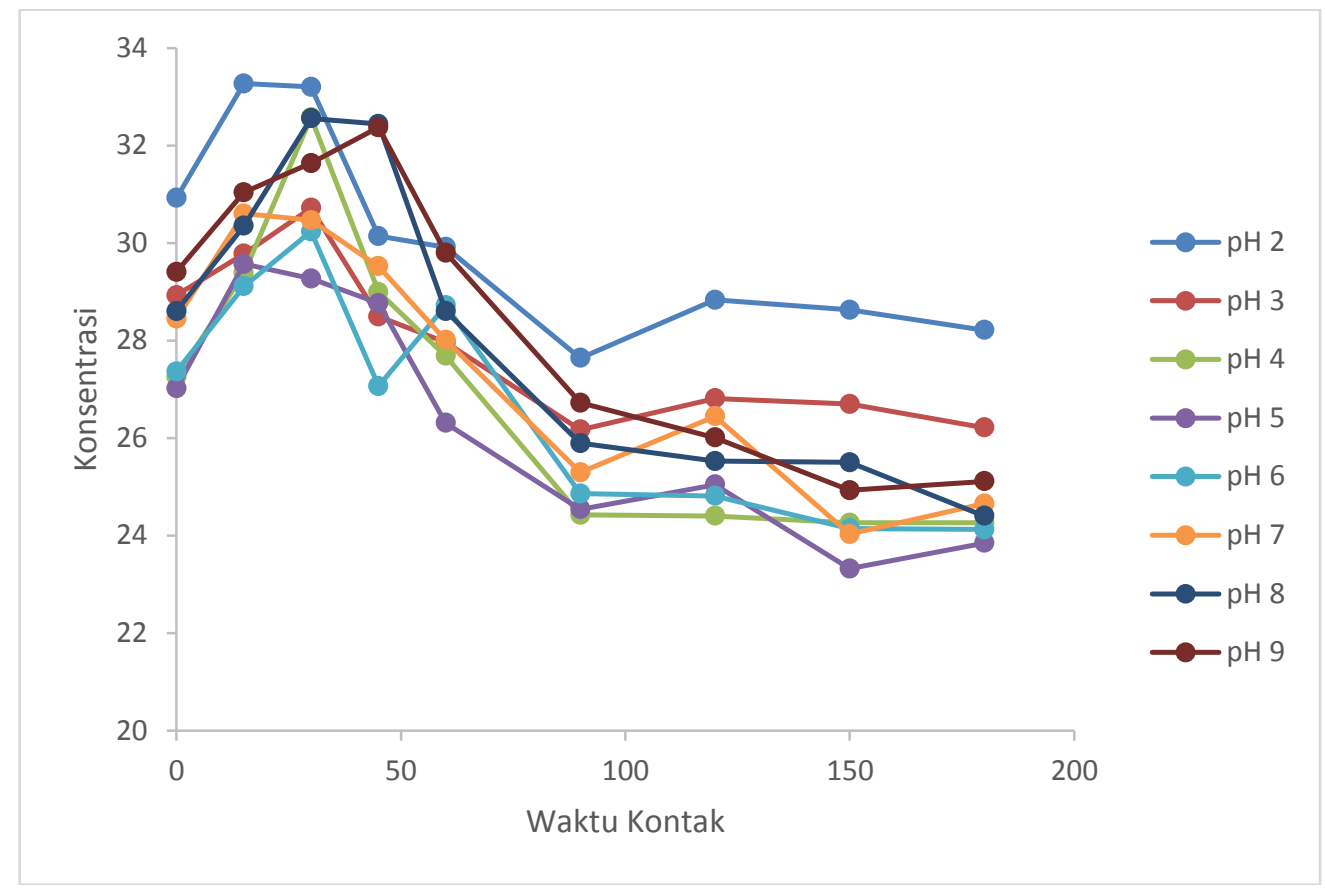

Gambar 2. Pengaruh pH Terhadap Konsentrasi Adsorpsi pembakaran $50^{\circ} \mathrm{C}$

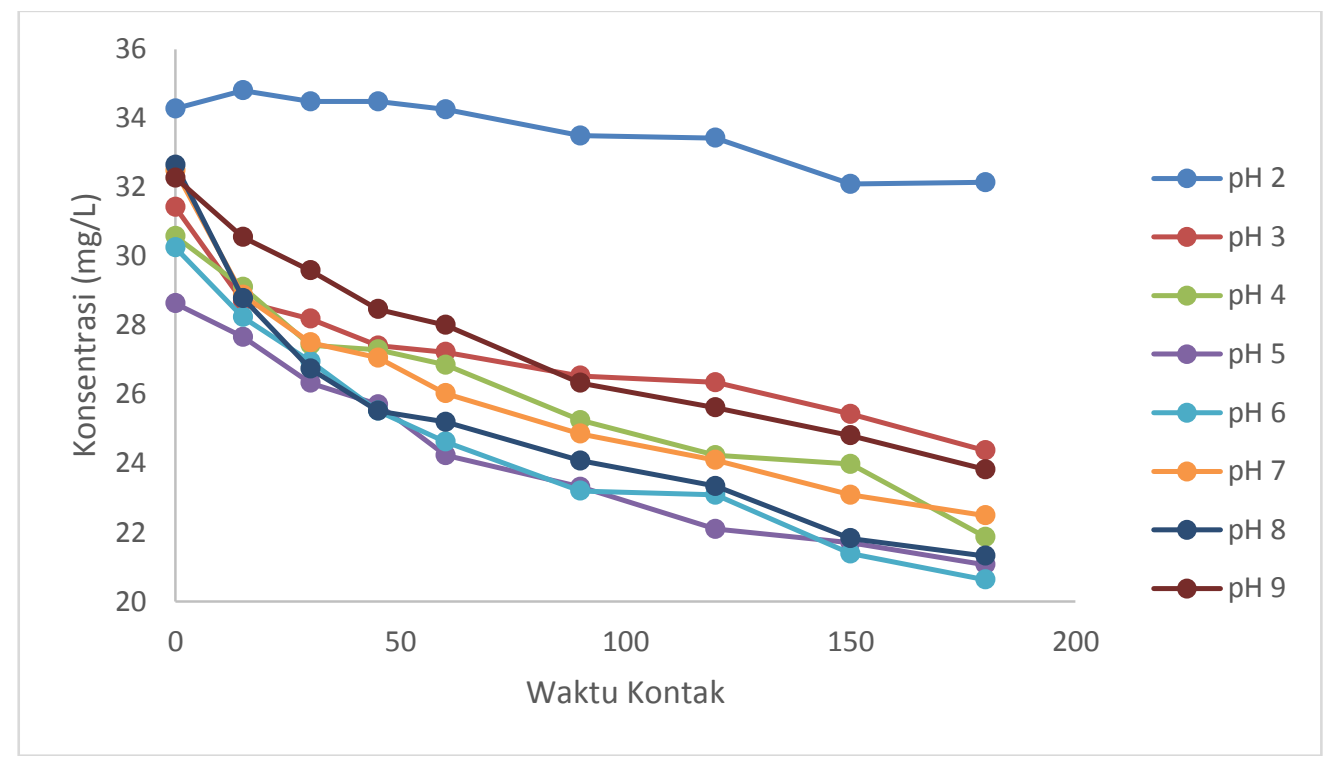

Gambar 3. Pengaruh pH Terhadap Konsentrasi Adsorpsi pembakaran 1000C

\subsection{Penentuan Waktu Kontak Optimum}

Waktu kontak merupakan salah satu yang berpengaruh terhadap proses adsorpsi untuk mengetahui kapasitas zat warna yang terserap dalam kurun waktu tertentu dengan massa adsorben yang tetap (Malviya dkk, 2019). Variasi waktu kontak yang terjadi adalah 15, 30, 45, 60, 90, 120, 150, dan 180 menit. pH optimum yaitu pH 5 didapatkan waktu kontak optimum pada pembakaran $50^{\circ} \mathrm{C}$ terjadi pada waktu kontak 90 menit dengan konsentrasi awal 27,019 mg/L turun menjadi 24,539mg/L dengan persentase adsorpsi sebesar 9,179\%. 
Sedangkan pada pembakaran $100^{\circ} \mathrm{C}$ waktu kontak optimum terjadi pada waktu kontak 180 menit dengan konsentrasi awal 30,257 mg/L turun menjadi 20,634 mg/L dengan persentase adsorpsi sebesar 31,804\%. Nilai serapan dapat dilihat pada gambar 4 dan gambar 5 berikut.

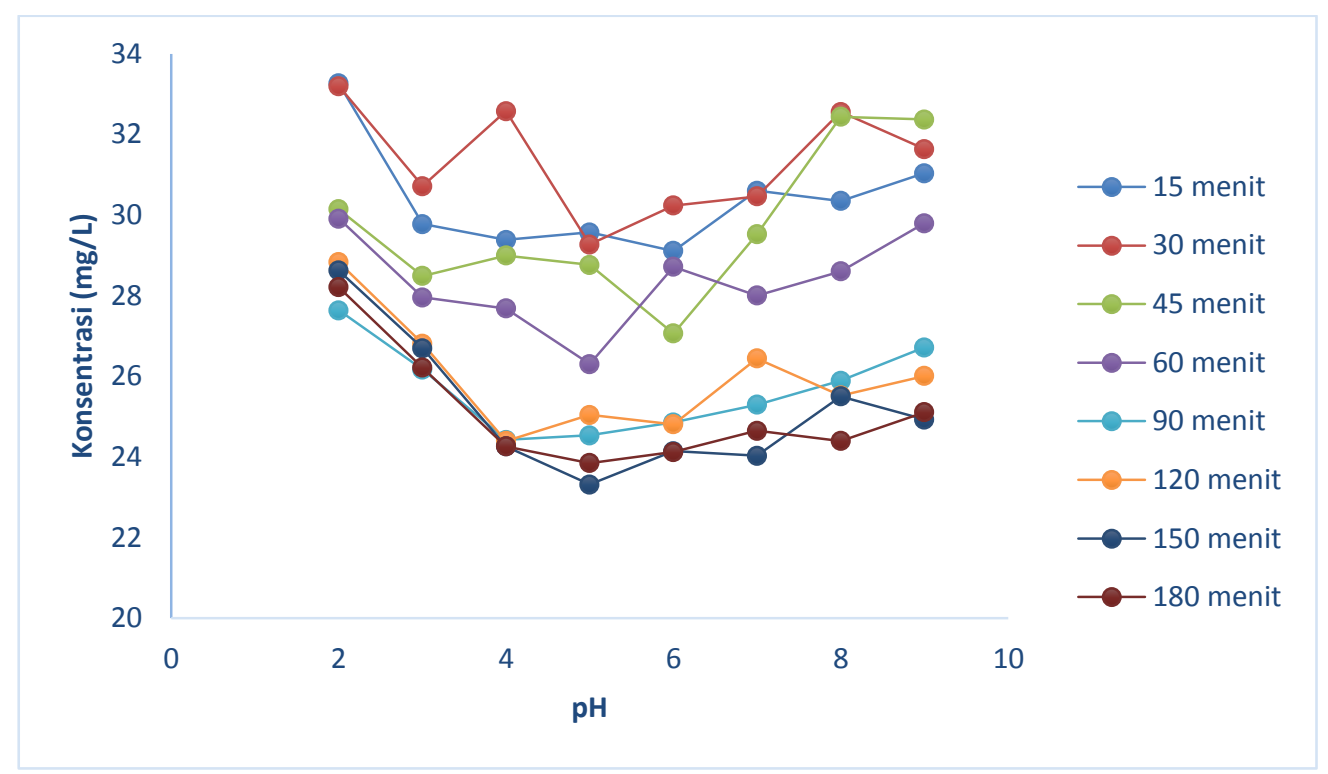

Gambar 4. Pengaruh Waktu Konntak Terhadap Konsentrasi Adsorpsi Pembakran 500C

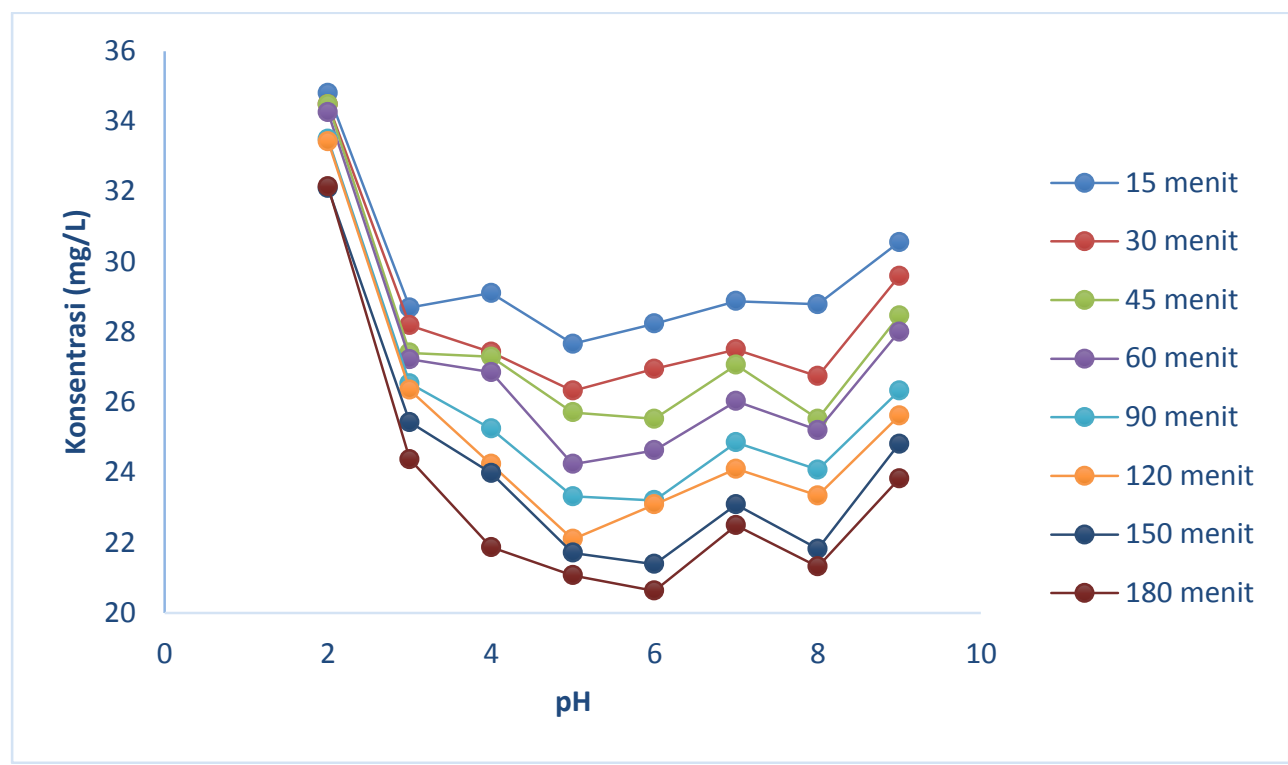

Gambar 5. Pengaruh Waktu Konntak Terhadap Konsentrasi Adsorpsi Pembakaran 1000C

\subsection{Uji Statistik Pengaruh pH dan Waktu Kontak}

Untuk mengetahui pengaruh $\mathrm{pH}$ dan waktu kontak terhadap konsentrasi serapan maka dibuat uji statstik regresi linier berganda dengan Hipotesis sebagai berikut:

$\mathrm{H}_{0} \quad$ : Tidak terdapat pengaruh $\mathrm{pH}\left(\mathrm{X}_{1}\right)$ terhadap Konsentrasi $(\mathrm{Y})$

$\mathrm{H}_{1} \quad$ : Terdapat pengaruh $\mathrm{pH}\left(\mathrm{X}_{1}\right)$ terhadap Konsentrasi $(\mathrm{Y})$

$\mathrm{H}_{0}{ }^{\prime} \quad$ : Tidak terdapat pengaruh $\mathrm{pH}\left(\mathrm{X}_{2}\right)$ terhadap Konsentrasi $(\mathrm{Y})$

$\mathrm{H}_{1}{ }^{\prime} \quad$ : Terdapat pengaruh Waktu Kontak $\left(\mathrm{X}_{2}\right)$ terhadap Konsentrasi $(Y)$

$\mathrm{H}_{0}{ }^{\prime \prime} \quad$ : Tidak terdapat pengaruh $\mathrm{pH}\left(\mathrm{X}_{1}\right)$ dan waktu kontak $\left(\mathrm{X}_{2}\right)$ terhadap Konsentrasi $(\mathrm{Y})$

$\mathrm{H}_{1}{ }^{\prime \prime} \quad$ : Terdapat pengaruh $\mathrm{pH}\left(\mathrm{X}_{1}\right)$ dan Waktu Kontak $\left(\mathrm{X}_{2}\right)$ terhadap Konsentrasi $(\mathrm{Y})$ 
Tingkat kepercayaan 95\%, $\alpha=5 \%$

Dengan dasar pengambilan keputusan berdasarkan:

a. Uji t

- Jika nilai signifikan $<0,05$, atau $\mathrm{t}$ hitung $>\mathrm{t}$ tabel maka terdapat pengaruh variabel $\mathrm{X}$ terhadap variabel $Y$

- Jika nilai signifikan $>0,05$, atau $t$ hitung $<\mathrm{t}$ tabel maka tidak terdapat pengaruh variabel $X$ terhadap variabel $Y$

Rumus : $\quad \mathrm{t}$ tabel $=\mathrm{t}(\mathrm{a} / 2 ; \mathrm{n}-\mathrm{k}-1)=\mathrm{t}(0,025 ; 72-2-1)$

b. Uji F

$$
=\mathrm{t}(0,025 ; 69)=1,994
$$

- Jika nilai signifikan $<0,05$, atau $F$ hitung $>\mathrm{F}$ tabel maka terdapat pengaruh variabel $\mathrm{X}$ secara simultan terhadap variabel $\mathrm{Y}$.

- Jika nilai signifikan > 0,05, atau $F$ hitung $<\mathrm{F}$ tabel maka tidak terdapat pengaruh variabel $X$ secara simultan terhadap variabel $Y$.

Rumus : $\mathrm{F}$ tabel $=\mathrm{F}(\mathrm{k} ; \mathrm{n}-\mathrm{k})=\mathrm{F}(2 ; 72-2)$

$$
=F(2 ; 70)=3,13
$$

Berikut disajikan data Koefisien dan Anova untuk pembakaran $50^{\circ} \mathrm{C}$ pada masing-masing tabel 2 dan tabel 3.

Berdasarkan tabel 1 dan 2 diatas maka dapat diambil keputusan sebagai berikut :

Nilai sig. untuk pengaruh $X_{1}$ terhadap $Y$ sebesar 0,318 $>0,05$ dan nilai t hitung $<t$ tabel 1,994. Artinya tidak terdapat pengaruh yang signifikan $\mathrm{pH}\left(\mathrm{X}_{1}\right)$ terhadap $\mathrm{Y}$

- Nilai sig. untuk pengaruh $X_{2}$ terhadap $Y$ sebesar $0,000<0,05$ dan nilai t hitung $<\mathrm{t}$ tabel 1,994. Artinya terdapat pengaruh waktu $\operatorname{kontak}\left(X_{2}\right)$ terhadap $Y$

- Nilai signifikan pengaruh $X_{1}$ dann $X_{2}$ secara simultan terhadap $Y$ sebesar 0,000 $<0,05$ dan nilai $F$ hitung $>F$ tabel 3,13. Artinya terdapat pengaruh $X_{1}$ dan $X_{x}$ secara bersama-sama terhadap Y.

Berikut disajikan data Koefisien dan Anova untuk pembakaran $100^{\circ} \mathrm{C}$ pada masing-masing tabel 4 dan tabel 5.

Berdasarkan tabel 1 dan 2 diatas maka dapat diambil keputusan sebagai berikut :

- Nilai sig. untuk pengaruh $X_{1}$ terhadap $Y$ sebesar 0,000 $>0,05$ dan nilai $t$ hitung $<t$ tabel 1,994. Artinya terdapat pengaruh $\mathrm{pH}\left(\mathrm{X}_{1}\right)$ terhadap $\mathrm{Y}$.

- Nilai sig. untuk pengaruh $X_{2}$ terhadap $Y$ sebesar 0,000 $<0,05$ dan nilai $t$ hitung $<\mathrm{t}$ tabel 1,994. Artinya terdapat pengaruh waktu kontak $\left(X_{2}\right)$ terhadap $Y$.

- Nilai signifikan pengaruh $X_{1}$ dann $X_{2}$ secara simultan terhadap $Y$ sebesar 0,000 $<0,05$ dan nilai $F$ hitung $>F$ tabel 3,13. Artinya terdapat pengaruh $X_{1}$ dan $X_{2}$ secara bersama-sama terhadap Y.

Tabel 2. Koefisien Pembakaran 500C

\begin{tabular}{|c|c|c|c|c|c|c|}
\hline \multirow{2}{*}{ Model } & \multicolumn{2}{|c|}{$\begin{array}{c}\text { Unstandardized } \\
\text { Coefficients }\end{array}$} & $\begin{array}{c}\text { Standardized } \\
\text { Coefficients }\end{array}$ & \multirow{2}{*}{$\mathrm{t}$} & \multirow{2}{*}{ Sig. } \\
\cline { 3 - 5 } & $\mathrm{B}$ & Std. Error & Beta & & \\
\hline \multirow{3}{*}{1} & $($ Constant $)$ & 30.834 & .615 & & 50.103 & .000 \\
\cline { 2 - 7 } & $\mathrm{pH}\left(\mathrm{X}_{1}\right)$ & -.093 & .092 & -.081 & -1.005 & .318 \\
\cline { 2 - 7 } & $\begin{array}{c}\text { Waktu } \\
\text { Kontak }\left(\mathrm{X}_{2}\right)\end{array}$ & -.033 & .004 & -.737 & -9.129 & .000 \\
\hline \multicolumn{7}{|c|}{ a. Dependent Variable: Konsentrasi } \\
\hline
\end{tabular}


Tabel 3. Anova Pembakaran 500C

\begin{tabular}{|c|c|c|c|c|c|c|}
\hline \multicolumn{2}{|c|}{ Model } & $\begin{array}{c}\text { Sum of } \\
\text { Squares }\end{array}$ & $\mathrm{df}$ & Mean Square & $\mathrm{F}$ & Sig. \\
\hline \multirow{3}{*}{1} & Regression & 272.048 & 2 & 136.024 & 42.175 & $.000^{\mathrm{b}}$ \\
\cline { 2 - 7 } & Residual & 222.541 & 69 & 3.225 & & \\
\cline { 2 - 7 } & Total & 494.589 & 71 & & & \\
\hline \multicolumn{6}{|c|}{ a. Dependent Variable: Konsentrasi (Y) } \\
\hline \multicolumn{6}{|c|}{ b. Predictors: (Constant), Waktu Kontak (X2), pH (X1) } \\
\end{tabular}

Tabel 4. Koefisien Pembakaran 1000C

\begin{tabular}{|c|c|c|c|c|c|c|}
\hline & \multirow[t]{2}{*}{ Model } & \multicolumn{2}{|c|}{$\begin{array}{c}\text { Unstandardized } \\
\text { Coefficients }\end{array}$} & \multirow{2}{*}{$\begin{array}{c}\text { Standardized } \\
\text { Coefficients } \\
\text { Beta }\end{array}$} & \multirow[t]{2}{*}{$\mathrm{t}$} & \multirow[t]{2}{*}{ Sig. } \\
\hline & & $\mathrm{B}$ & Std. Error & & & \\
\hline \multirow{3}{*}{1} & (Constant) & 33.414 & .905 & & 36.917 & .000 \\
\hline & $\mathrm{pH}(\mathrm{X} 1)$ & -.603 & .136 & -.367 & -4.439 & .000 \\
\hline & $\begin{array}{c}\text { Waktu } \\
\text { Kontak (X2) }\end{array}$ & -.040 & .005 & -.627 & -7.580 & .000 \\
\hline \multicolumn{7}{|c|}{ a. Dependent Variable: Konsentrasi $(\mathrm{Y})$} \\
\hline
\end{tabular}

Tabel 5. Koefisien Pembakaran 1000C

\begin{tabular}{|c|c|c|c|c|c|c|}
\hline \multicolumn{2}{|c|}{ Model } & $\begin{array}{c}\text { Sum of } \\
\text { Squares }\end{array}$ & $\mathrm{df}$ & Mean Square & $\mathrm{F}$ & Sig. \\
\hline \multirow{3}{*}{1} & Regression & 538.317 & 2 & 269.159 & 38.582 & $.000^{\mathrm{b}}$ \\
\cline { 2 - 7 } & Residual & 481.367 & 69 & 6.976 & & \\
\cline { 2 - 7 } & Total & 1019.685 & 71 & & & \\
\hline \multicolumn{6}{|c|}{ a. Dependent Variable: Konsentrasi (Y) } \\
\hline
\end{tabular}

\subsection{Penentuan Pembakaran Optimum}

Pembakaran bottom ash bertujuan untuk mengaktivasi bottom ash yang dilakukan secara fisika. Berdasarkan perbandingan konsentrasi penyerapan, pembakaran pada temperatur $100^{\circ}$ menyerap lebih banyak konsentrasi zat warna jika dibandingkan dengan pembakaran pada temperature $50^{\circ} \mathrm{C}$. Nilai konsentrasi dapat dilihat pada gambar 6

\subsection{Penentuan kapasitas adsorpsi}

Penentuan kapasitas adsorpsi dilakukan dengan menggunakan kurva isotherm Langmuir dan Freundlich. Menurut Lestari (2015) nilai $\mathrm{R}^{2}$ pada grafik isotherm yang paling mendekati 1 , menunjukkan bahwa pola adsorpsi mengikuti pola isotherm tersebut. Berdasarkan nilai $\mathrm{R}^{2}$ isotherm Freundlich yang hampir mendekati 1 yaitu sebesar 0,9287 maka dapat dikatakan bahwa pola adsorpsi ini mengikuti pola ishoterm adsorpsi Freundlich. Berikut disajikan gambar isotherm adsorpsi Langmuir dan Freundlich. 


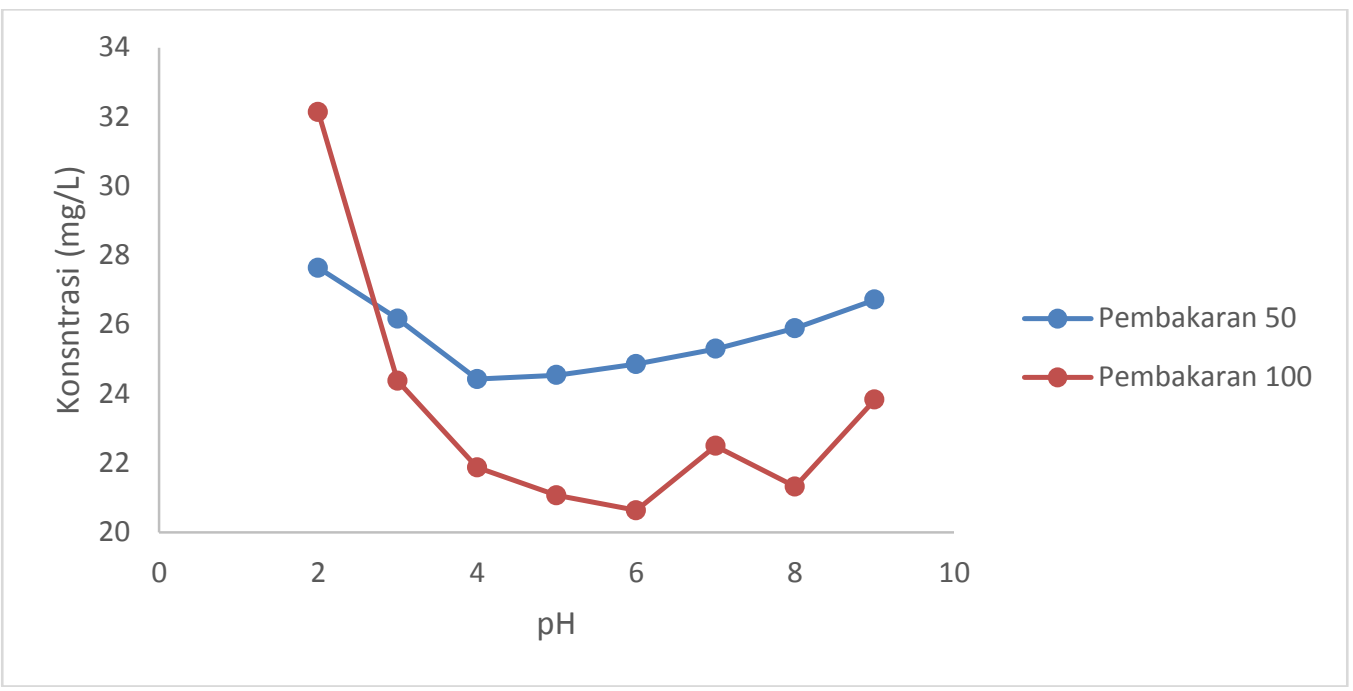

Gambar 6. Pengaruh Pembakaran Bottom Ash Terhadap Konsentrasi Adsorpsi

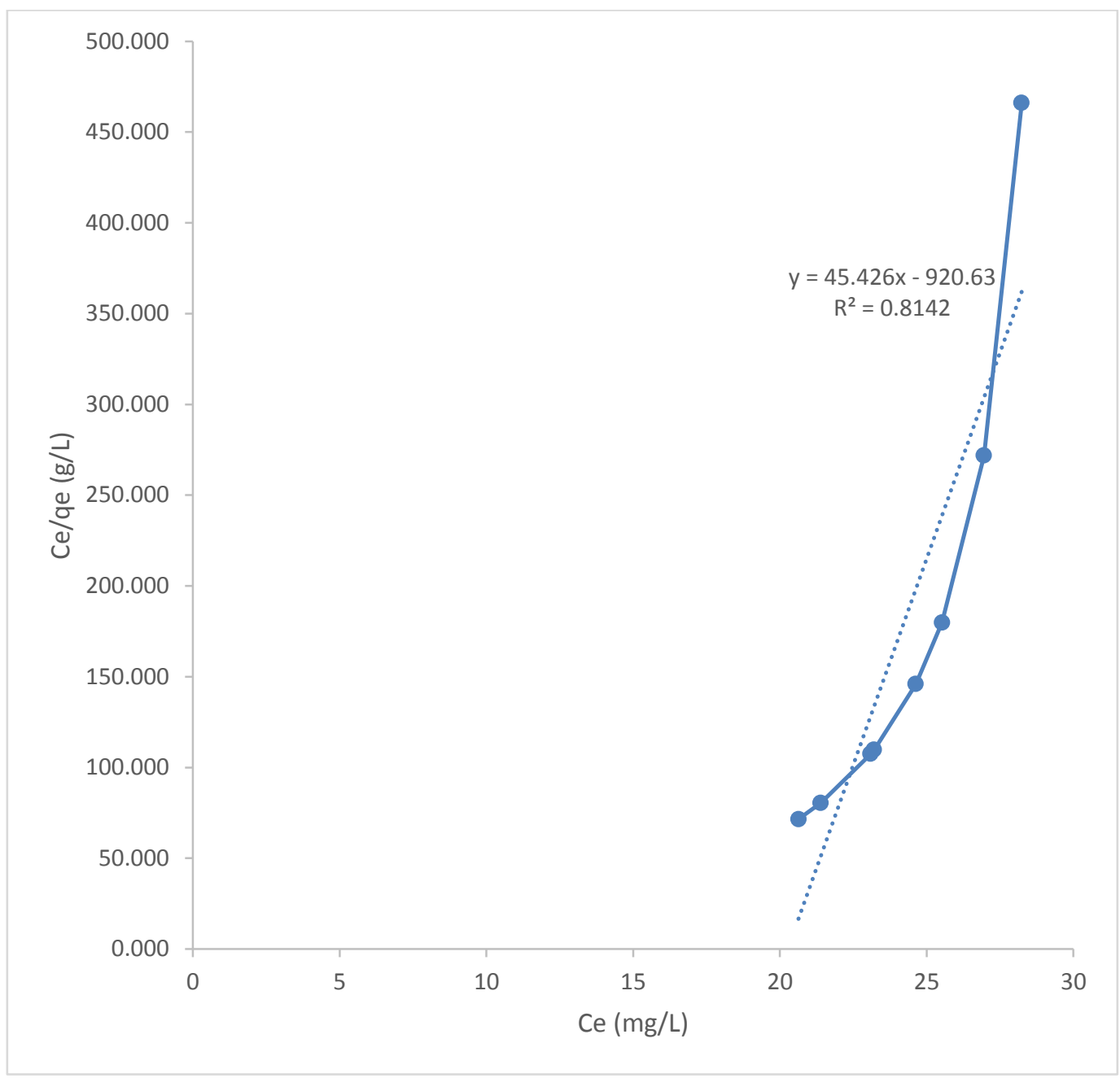

Gambar 7. Isotherm Adsorpsi Langmuir 


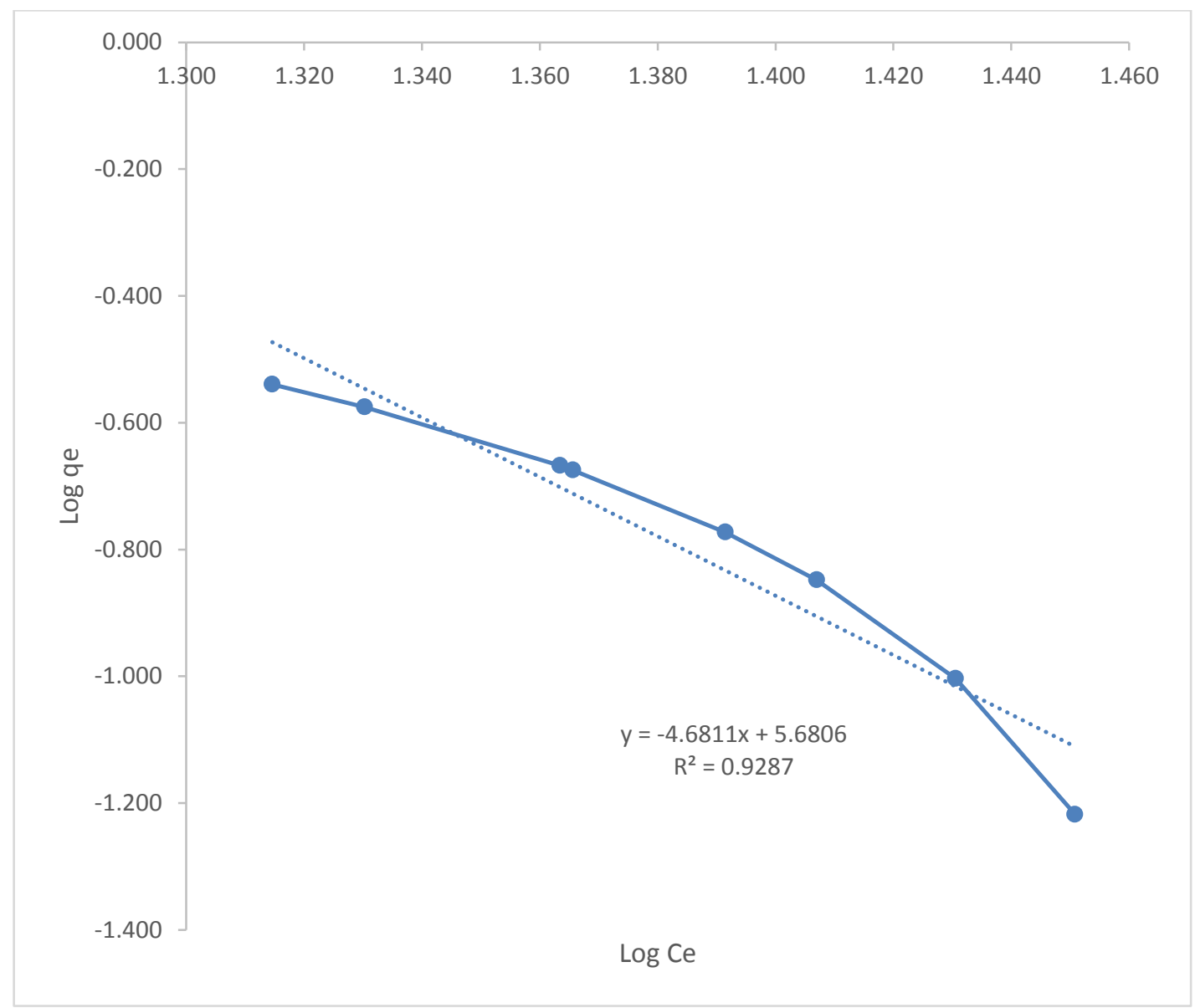

Gambar 8. Isotherm Adsorpsi Freundlich

\section{KESIMPULAN}

Berdasarkan penelitian yang dilakukan mengenai kemampuan bottom ash untuk dijadikan sebagai adsorben untuk mengurangi zat warna dalam limbah cair industri tekstil dapat disimpulkan sebagai berikut :

1. Berdasarkan studi literatur mengenai hasil uji XRF untuk mengetahui karakteristik bottom ash, didapatkan bahwa bottom ash memiliki komposisi kandungan $\mathrm{Si}, \mathrm{Al}, \mathrm{Fe}$, dan Ca yang lebih besar dibandingkan dengan komposisi senyawa lainnya

2. Pembakaran $100^{\circ} \mathrm{C}$ memiliki penyerapan kapasitas adsorpsi yang lebih besar yaitu $34,694 \%$ dibandingkan dengan pembakaran $50^{\circ} \mathrm{C}$ sebesar $15,508 \%$

\section{DAFTAR RUJUKAN}

Apriyanti, H., I Nyoman Candra, Elinawati. 2018. Karakterisasi Isoterm Adsorpsi dari Ion Logam Besi (Fe) Pada Tanah Di Kota Bengkulu. Jurnal Pendidikan dan Ilmu Kimia.

Ayuni, Ni Putu Sri. Ni Wayan Yuningrat. Ketut Yesi A. (2016). Adsorpsi-Desorpsi Zat Warna Azo Jenis Remazol Black B Menggunakan Membran Polielektrolit (PEC) Kitosan-Pektin. Bali. 
Benzaoui, Thouria., Ammar S., Djaafar D. (2017). Adsorption of Copper (II) Ions from Aqueous Solution Using Bottom Ash of Expired Drugs Incineration. Adsorption Science and Technology.

Bertolini, T. C. R., Juliana C. Izidoro., Carina, P. M., Denise A. F. (2013). Adsorption of Crystal Violet Dye from Aqueous Solution onto Zeolites from Coal Fly and Bottom Ashes. Chemical and Environmentak Center, Nuclear and Energy Research Institute.

Christina P.M., Mu'nisatun S., Saptaaji R., dan Marjanto D. (2007). Studi Pendahuluan Mengenai Degradasi Zat Warna Azo (Metil Orange) Dalam Pelarut Air Menggunakan Mesin Berkas Elekron $350 \mathrm{Kev} / 10 \mathrm{Ma}$, JFN, No.1, Vol.1. 31-44

Chung, K.-T. (2016). Azo dyes and human health: A review. Journal of Environmental Science and Health, Part C, 34(4), 233-261. doi:10.1080/10590501.2016.1236602

Damayanti, Retno. (2018). Abu Batubara dan Pemanfaatannya: Tinjauan Teknis Karakteristik Secara Kimia dan Toksikologinya. Jurnal Teknologi Mineral dan Batubara Volume 14, No 3.

Dong, L., Z. Zhu, Y. Qiu, and J. Zhao. 2010. Removal of Lead From Aqueous Solution by Hidroxyapatite/Magnetite Composite Adsorbent. Chemical Engineering Journal. Vol. 16, No. $5: 827-834$.

Fitriyana, D. F. dan Sulardjaka. 2012. Sintesis Zeolit A Berbahan Dasar Limbah Geotermal dengan Metode Hidrotermal. Simposium Nasional RAPI XI FT UMS. Jurusan Teknik Mesin Fakultas Teknik Universitas Diponegoro.

Gičević, A., Hindija, L., \& Karačić, A. (2019). Toxicity of Azo Dyes in Pharmaceutical Industry. CMBEBIH 2019, 581-587.

Hecker., dan Bilski, J. (2014). Environmental Toxicology and Coal Fly Ash Chemical Composition. Research Journal of Chemical and Environmental Science, 2(4), pp. 27-33. Herfina, Herny. (2017). Analisis Ekonomi dan Lingkungan Pemanfaatan Limbah Fly Ash Pada Pembangkit Listrik Tenaga Uap (Studi Kasus PT XYZ Cilegon). Bogor : Institut Pertanian Bogor.

Hutagalung, Deby Evelin. 2018. Dekolorisasi Pewarna Tekstil Sintetis Azo oleh Bakteri Halotoleran dan Identifikasi Menggunakan 16S rRNA. Universitas Sumatera Utara.

Jayaranjan, M. L. D., van Hullebusch, E. D., \& Annachhatre, A. P. (2014). Reuse options for coal fired power plant bottom ash and fly ash. Reviews in Environmental Science and Bio/Technology, 13(4), 467

Kusmiyati, Puspita adi L., Deni Vitasari., Robi Indra., Dila Islamica., dan Hadiyanto. (2016). Coal Bottom Ash and Activated Carbon for Removal of Vertigo Blue Dye in Batik Textile 
Waste Water : Adsorbent Characteristic, Ishoterms, and Kinetics Studies. Semarang : Universitas Diponegoro.

Lestari, Indah Puji. (2015). Efektivitas Bentonoit Teraktivasi Sebagai Penurun Kadar Ion Fosfat Dalam Perairan. Semarang : Universitas Negeri Semarang.

Malviyah, A., Dipika K. J., dan Shraddha K. (2019). Kinetics Studies On the Adsorption of methyl Orange and Metanil yellow Oto Bottom Ash : A Comprative Account. Water Science and Technology.

Tarigan, Budi Pratama. (2019). Pemanfaatan Bottom Ash Batubara Untuk Menurunkan Kandungan Fosfat Pada Limbah Deterjen dengan Aktivator $\mathrm{NaOH}$. Universitas Sumatera Utara.

Wardani, Ratih Kusuma. (2012). Pemanfaatan Abu Bawah Batubara (Bottom Ash) Teraktivasi Sebagai Adsorben Ion Logam Cd2+. Universitas Airlangga.

Yildirim, M., Nevin, K. M., Funda, D., Emek, M. D. (2017). Removal of As (V) By Using Bottom Ash As Adsorbent. CBU International Conference on Innovation in Science and Education.

Yunita, Eka. (2017). Analisis Potensi dan Karakteristik Limbah Padat Fly Ash dan Bottom Ash Hasil dari Pembakaran Batubara Pada Pembangkit Listrik Tenaga Uap (PLTU). Makassar : UIN Alauddin. 